\title{
Effect of different Organic and Inorganic Coatings on Physico-chemical, Microbiological and Sensorial attributes of Fresh-Cut Muskmelon
}

\author{
Pallavi M. Kale, Ujjwala B. Palghadmal, Supriya S. Patil
}

Department of Horticulture, College of Agriculture, Kolhapur, MPKV Rahuri, Maharashtra, India

\begin{abstract}
Eight different organic and inorganic dipping treatments viz., organic coatings- 10\% honey, 20\% honey, Aloe vera gel, $10 \% \mathrm{WPC}$ and inorganic coatings-calcium chloride $\left(2.5 \%\right.$ at $\left.20^{\circ} \mathrm{C}\right)$, calcium chloride $\left(2.5 \%\right.$ at $\left.60^{\circ} \mathrm{C}\right)$, calcium lactate $(1 \%), 0.1 \%$ nanosilver stipulated food grade level $\mathrm{H}_{2} \mathrm{O}_{2}$ along with control were used for pretreatment of fresh-cut muskmelon. The changes in physico-chemical parameters were slow in the fresh-cut muskmelon treated with organic (10\% WPC) and inorganic $(0.1 \%$ nanosilver stipulated food grade level $\left.\mathrm{H}_{2} \mathrm{O}_{2}\right)$ dipping under refrigerated storage $\left(5 \pm 1^{\circ} \mathrm{C}\right)$ up to 18 days. Minimum changes in TSS were recorded in fresh-cut muskmelon pretreated with Aloe vera gel $\left(A_{4}\right)$. The maximum physiological loss in weight and per cent decay was observed in control treatment. The minimum microbial count was observed in fresh-cut muskmelon fruit treated with $0.1 \%$ nanosilver stipulated food grade $\mathrm{H}_{2} \mathrm{O}_{2}\left(\mathrm{~A}_{9}\right)$ followed by $10 \%$ WPC treatment $\left(A_{5}\right)$. Among the different organic and inorganic dipping studied, organic pretreatment of fresh-cut muskmelon with 10\% WPC was found best, as regards, inorganic dipping (coatings), $0.1 \%$ nanosilver stipulated food grade $\mathrm{H}_{2} \mathrm{O}_{2}$ was next best. Both the dipping treatments extended shelf life of fresh-cut muskmelon up to 18 days.
\end{abstract}

Keywords - fresh-cut muskmelon, calcium lactate, WPC, microbial count, shelf life, $\mathrm{H}_{2} \mathrm{O}_{2}$.

\section{INTRODUCTION}

Muskmelon (Cucumis melo L.), a predominant edible fruit belonging to Cucurbitaceae family, is fourth important fruit in the world fresh fruit and fresh-cut market with several varieties and serves as major food sources. It is usually characterized by netted surfaces with shallow vein tracts and flesh is salmon-coloured. Muskmelon is native to North Western parts of India and its primary center of origin is hot valley of Iran and adjacent areas; now growing worldwide in both tropical and temperate regions. In India, muskmelon is grown on an area of 45000 ha with production of 9.35 lakh MT (Anon, 2016). It is common component of fresh cut fruit product and popular for their pleasant odour and sweet taste (Villanueva et al., 2004). The preparation is needed for muskmelon before consumption which makes them suitable to be processed as fresh-cut fruit (Amaro et al., 2012).
However, due to rapid deterioration rate and enhanced ethylene productivity, muskmelon has lower shelf life so its market is not widespread. Consumers expect fresh-cut products to be without defects, of optimum maturity, fresh appearance, and have high sensory and nutrient quality (Watada and Qi, 1999). Hence, high quality of raw product is necessary to achieve high quality fresh-cut product. Final product can only be as good as the incoming raw product. Effective microbial control is essential to restrict high respiration rate which causes spoilage and give unpleasant flavor and odour. The number of processing techniques currently used by the fresh-cut industry is use of low temperature, antioxidants, surfactants, sanitizers and modified atmosphere packaging (MAP). Applications of edible coating on fruits have the same effect as modified atmosphere packaging (MAP) in modifying the internal gas composition (Park, 1999). The appropriate edible coating formulation may reduce gas exchange rates and water loss as well as represent an excellent way of incorporating 
additives to control reactions that are detrimental to quality (Baldwin, Nisperos-Carriedo and Barker, 1995). Edible organic coating can be developed from proteins, polysaccharides, lipids, or from a blend of these groups of material (Kester and Fennema, 1988). The Aloe vera gel is used for fresh-cut fruit coating. Aloe vera gel provides a barrier to oxygen and water movement, had no effect to the taste (Bernstein, 2005) and also has antimicrobial activity. The numerous chemical and physical preservation strategies retarding cut fruit tissue ripening are used (Reyes, 1996). The use of honey treatments has also been explained in preserving the fresh-like quality of minimally processed fruits and vegetables and to extend their shelf life. Honey has been used since ancient times as a sweetening agent in food and is one of the concentrated natural forms of sugar available worldwide. In addition several inorganic dipping treatments of calcium compound were also used as a firming agent in processing industry.

\section{MATERIALS AND METHODS}

\section{Plant material}

The well matured, sound, healthy and fresh fruits of muskmelon (Cucumis melo L.) cv. Kundan were collected from Instructional-cum-research farm of Horticulture section, College of Agriculture, Kolhapur. The cubes of $3.5 \times 3.5 \mathrm{~cm}$ size were prepared and used for research.

\section{Sample preparation}

The defect free, good healthy ripe muskmelon fruits were selected. An overripe and unripe fruits were rejected. The fruits were washed with tap water and disinfected by dipping in sodium hypochlorite solution $(100 \mathrm{ppm})$ for 2 minutes. All tools and equipment were sanitized with sodium hypochlorite solution $(150 \mathrm{ppm})$ prior to fresh-cut processing. Both blossom and pedicel ends including the calyx of each fruit were removed with a sharp knife and then cut longitudinally in to slices. The seeds were removed from the cavity. The slices were cut into cubes, with approximate dimension of $3.5 \times 3.5 \mathrm{~cm}$. During the cutting process, fruit with internal defects were discarded. The healthy and freshcut fruit cubes were divided into lots for further treatments of viz. organic coatings- $10 \%$ honey, $20 \%$ honey, Aloe vera gel, $10 \%$ WPC and inorganic coatings- calcium chloride (2.5\% at $\left.20^{\circ} \mathrm{C}\right)$, calcium chloride $\left(2.5 \%\right.$ at $\left.60^{\circ} \mathrm{C}\right)$, calcium lactate (1\%), $0.1 \%$ nanosilver stipulated food grade level $\mathrm{H}_{2} \mathrm{O}_{2}$ along with control were used for pretreatment of fresh-cut muskmelon. The treated fresh-cut muskmelon sample weighing $250 \mathrm{~g}$ were packed in glass pint glass jars and stored in two different environments i.e. in refrigerated storage at $5 \pm 10 \mathrm{C}$ and at ambient temperature.

\section{Physico-chemical determinations}

The determination of hardness was done by using a fruit pressure tester (Penetrometer) (make Nieuwlcoop BV Model FT 327) by measuring the maximum penetration force. Weight loss was estimated based on the fresh produce weight and the significant change in physiological weight loss of fresh-cut muskmelon cubes during storage was determined on percentage basis. In all samplings, the fresh weight was measured by an electronic scale of $\pm 0.01 \mathrm{~g}$ accuracy and reduction in weight over initial weight in percentage was calculated according to Song et al. (2013). The percent decay of fresh-cut muskmelon cubes during storage was calculated based on visual inspection of each fresh-cut cube for infection. Percent decay was calculated according to Gihan (2010) on weight basis. The content of TSS in fresh-cut muskmelon cubes was estimated by using Atago, Tokyo hand refractometer and the values were corrected to $20^{\circ} \mathrm{C}$ with the help of temperature correction chart (A.O.A.C., 2005) and expressed in percentage. The titratable acidity of fresh-cut muskmelon cubes was determined by anhydrous citric acid by titrating 10 milliliter juice against $0.1 \mathrm{~N} \mathrm{NaOH}$ using phenolphthalein as an indicator as per method advocated by A.O.A.C. (2005).

\section{Microbial analysis:}

Microbiological growth in fresh-cut muskmelon cubes was observed as total plate count (TPC) and yeast and mould (YM). The method suggested by Luna-Guzman and Barrett (2000) and Silveira et al. (2011) was used for microbial analysis.

From each replicate, three random fresh-cut muskmelon cubes of $10 \mathrm{~g}$ were collected using sterile techniques from a polypropylene container and homogenized with $90 \mathrm{ml}$ of sterile Ringer solution in a sterile stomacher bag for 1 minute. Serial dilutions needed for sample plating were prepared in $9 \mathrm{ml}$ of ringer solution. The pour plate method was performed using the following media and culture conditions: Plate Count Agar for TPC and Potato Dextrose Agar for yeast and mould counts with added 10\% tartaric acid to attain PH 3.5. Both the media of the TPC and the yeast and mould count were incubated at $35 \pm 1^{\circ} \mathrm{C}$ for 48 hours and $25 \pm 1^{\circ} \mathrm{C}$ for 5 days, respectively. The microbial counts were expressed as $\log 10\left(\mathrm{cfu} \mathrm{g}^{-1}\right)$. According to microbial legislation, the maximum tolerated counts is 7 
$\log 10\left(\mathrm{cfu} \mathrm{g}^{-1}\right)$ for aerobic bacteria and $5 \log 10\left(\mathrm{cfu} \mathrm{g}^{-1}\right)$ and 3 $\log 10\left(\mathrm{cfu} \mathrm{g}^{-1}\right)$ the yeast and mould respectively.

\section{Sensorial analysis}

Subjective overall acceptability measurements were done on the basis of flavour, colour and appearance, taste and microbial limit tests parameters of samples by a panel of testers based on rating with nine point Hedonic scale suggested by Silvina et al. (1998) was considered (Appendix I). A score of 6 was considered the limit of acceptability.

\section{Statistical analysis}

The data was reported as an average value of replicates with standard deviation. Analysis of variance (ANOVA) was performed using IBM SPSS statistics 22 (Windows 8.1, Statistical analysis). The level of significance for all the tests was $\alpha=0.05$. Followed by Duncan's Multiple Range Test $(\mathrm{P} \leq 0.05)$ was carried out to evaluate significant statistical difference of data. For the data expressed as proportions arc sine transformation was applied before analysis.

\section{RESULTS AND DISCUSSION}

\section{Firmness}

Firmness of fresh-cut muskmelon decreased gradually with the advancement of storage period irrespective of the dipping treatments. Among all the treatments tried, fresh-cut muskmelon fruit pretreated with $1 \%$ Calcium Lactate $\left(\mathrm{A}_{8}\right)\left(3.267 \mathrm{~kg} / \mathrm{cm}^{2}\right)$ and $10 \%$ WPC $\left(\mathrm{A}_{5}\right)$ $\left(3.233 \mathrm{~kg} / \mathrm{cm}^{2}\right)$ (Fig. 1) retained significantly maximum total firmness throughout the storage period. This might be due to the cell binding properties of calcium lactate which improved the firmness by maintaining turgor, membrane integrity and inhibit lipase activity in cantaloupe fruits as reported by Syahidah et al., 2015; Lamikanra and Watson, 2004 in freshcut cantaloupe. This might be due to the active proteins present in WPC which reduced moisture loss and surface wounding holding the fresh cut tissues firmly as reported by Zsivanovits et al. (2012), Silveira et al. (2011) in fresh cut muskmelon and Ghavidel et al. (2013) in fresh cut apples.

\section{Physiological loss in weight}

Weight loss is a primary problem in losing weight by reducing moisture content from fruits through rapid ripening and respiration processes which ultimately become the reason of quick transpiration process (Khuram et al., 2015). By decreasing the turgor pressure and firmness of fruit, the weight loss starts to increase which become reason for becoming softer fresh-cut fruits (Beaulieu and Gorny, 2002). Significantly minimum physiological loss in weight (2.367\%) (Fig. 1) was recorded in $\mathrm{A}_{5}(10 \% \mathrm{WPC}$ ) followed by $\mathrm{A}_{9}(0.1 \%$ nanosilver stipulated food grade hydrogen peroxide) $(2.533 \%)$ treatment. This might be due to the active proteins and essential amino acids present in WPC and its viscoelastic wax property (Shellhammer and Krochta, 1997) which acts as a barrier for oxygen and moisture because of hydrophobicity due to their high content of longchain fatty alcohols and alkanes.

\section{Per cent decay}

Minimum per cent decay (6.357\%) (Table 1) was recorded in $\mathrm{A}_{9}(0.1 \%$ nanosilver stabilized food grade hydrogen peroxide) then followed by $\mathrm{A}_{5}(10 \%$ WPC) $(6.567 \%)$ with the advancement of time. This might be due to sterilization effect of nanosilver antibacterial biofilm coating on fresh cut muskmelon preventing enzymatic browning and discolouration of product. nanosilver stipulated/stabilized food grade hydrogen peroxide is highly effective broadspectrum disinfectant providing long lasting antimicrobial activity. The slow release of nanosilver stabilized food grade hydrogen peroxide provides mild protective barrier against decay-causing microorganisms as reported by Dhumal (2012) in pomegranate and Mukundan (2007) in fruits, vegetables and fishes. This could be due to the fact of protective firmness, antibrowning effect and antimicrobial effect of $10 \%$ whey protein concentrate as reported by PerezGago et al. (2006) in fresh-cut apples.

\section{Total Soluble Solids (TSS)}

In present study, reduction in total soluble solids was reported, which might have correlation with decrease of sugar content as studied by Koh et al. (2017). Aloe vera gel coating $\left(\mathrm{A}_{4}\right)$ recorded the minimum decrease in TSS (5.333 ${ }^{0}$ Brix) (Fig. 2) up to $18^{\text {th }}$ day of storage followed $10 \%$ honey coating $\left(\mathrm{A}_{2}\right)$ treatment which registered $\left(5.167{ }^{\circ} \mathrm{Brix}\right)$ in samples. The minimum reduction in TSS in Aloe vera gel treated samples might be due to the decrease in fresh cut fruit respiration rate as contributed by a film providing barrier for oxygen and refrigerated temperature of storage. Similar finding were reported by Koh et al. (2017), Yulianingsih et al. (2013), Machedo et al. (2008) and Lamikanra et al. (2000) in fresh cut cantaloupe melon. Honey has been used since ancient times as a sweetening agent in food and is only the concentrated form of sugar available worldwide reported (Dhumal et al., 2014). 

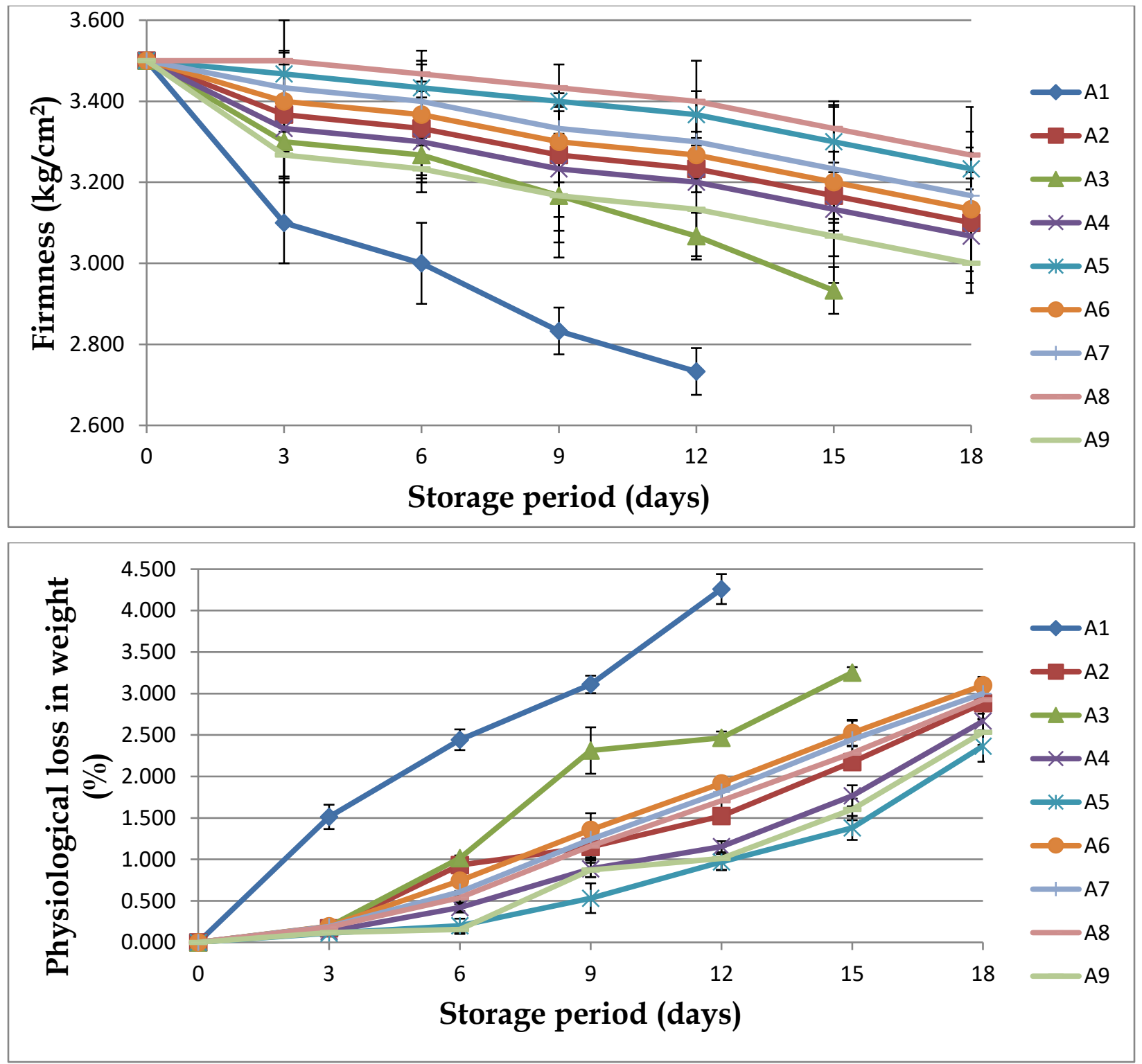

\section{Dipping treatments (Coatings):}

$\mathbf{A}_{1}=$ Control

$\mathbf{A}_{3}=20 \%$ Honey

$\mathbf{A} \mathbf{5}=10 \%$ Whey protein concentrations (WPC)

$\mathrm{A}_{7}=$ Calcium chloride $\left(2.5 \%\right.$ at $\left.60{ }^{\circ} \mathrm{C}\right)$
$\mathbf{A}_{2}=10 \%$ Honey

$\mathbf{A}_{4}=$ Aloe vera $\mathrm{gel}$

$\mathbf{A}_{6}=$ Calcium chloride $\left(2.5 \%\right.$ at $\left.20{ }^{\circ} \mathrm{C}\right)$

$\mathbf{A} 8=$ Calcium lactate $(1 \%)$

$\mathrm{A}_{9}=0.1 \%$ Nano silver stipulated Food grade level $\mathrm{H}_{2} \mathrm{O}_{2}$

Fig.1: Effect of dipping treatments (coatings) on the Firmness and physiological loss in weight of the fresh-cut muskmelon stored at refrigerated storage $5 \pm 1^{\circ} \mathrm{C}$. 


\section{Acidity}

Main organic acids muskmelons are malic and citric acids. (Lamikanra et al., 2000). An increase of acidity decreases in fruits and vegetables quality during storage period (Khuram et al., 2015). Minimum acidity (0.266\%) (Fig. 2) was recorded in $A_{2}$ (10\% honey) treated fresh-cut muskmelon. This was due to the pretreatment, packaging condition at low temperature that maintained cell turgidity, prevented microbiological deterioration, creation of anaerobic conditions, restricted availability of oxygen, endogenous enzymatic activities, reduced oxidation of sugars and organic acids, slow rate of moisture loss, reduced rate of bioactive compounds and slow non enzymatic browning as reported by Rolle and Chism in minimally processed fruits and vegetable, Dhumal et al. (2014) in pomegranate arils, Ergun and Ergun (2009) in arils of cv. Hicaznar and Gil et al. (1996) in cv. Mollar.

Table 1. Effect of dipping treatments (coatings) on the per cent decay of the fresh-cut muskmelon stored at $5 \pm l^{0} \mathrm{C}$.

\begin{tabular}{|c|c|c|c|c|}
\hline \multirow[t]{3}{*}{ Treatments } & \multicolumn{4}{|c|}{ Decay $(\%)$} \\
\hline & \multicolumn{4}{|c|}{ Storage period in days } \\
\hline & 9 & 12 & 15 & 18 \\
\hline$\overline{A_{1}}$ & $\begin{array}{c}7.180^{c} \\
(15.540)\end{array}$ & $\begin{array}{c}10.267^{f} \\
(18.687)\end{array}$ & - & - \\
\hline $\mathbf{A}_{2}$ & No decay & $\begin{array}{l}2.113^{b} \\
(8.357)\end{array}$ & $\begin{array}{c}4.500^{\mathrm{b}} \\
(12.237)\end{array}$ & $\begin{array}{c}7.803^{c} \\
(16.223)\end{array}$ \\
\hline $\mathbf{A}_{3}$ & $\begin{array}{l}1.900^{\mathrm{a}} \\
(7.920)\end{array}$ & $\begin{array}{c}5.793^{\mathrm{e}} \\
(13.927)\end{array}$ & $\begin{array}{c}9.067^{\mathrm{e}} \\
(17.527)\end{array}$ & - \\
\hline $\mathbf{A}_{4}$ & No decay & $\begin{array}{l}2.723^{c} \\
(9.500)\end{array}$ & $\begin{array}{c}5.383^{c} \\
(13.417)\end{array}$ & $\begin{array}{c}7.323^{b} \\
(15.697)\end{array}$ \\
\hline$\overline{A 5}$ & No decay & $\begin{array}{l}1.817^{\mathrm{a}} \\
(7.747)\end{array}$ & $\begin{array}{c}3.743^{\mathrm{a}} \\
(11.157)\end{array}$ & $\begin{array}{c}6.567^{\mathrm{a}} \\
(14.847)\end{array}$ \\
\hline$\overline{A_{6}}$ & $\begin{array}{l}2.740^{\mathrm{b}} \\
(9.527)\end{array}$ & $\begin{array}{c}5.637^{\mathrm{e}} \\
(13.733)\end{array}$ & $\begin{array}{c}8.167^{\mathrm{d}} \\
(16.603)\end{array}$ & $\begin{array}{c}10.080^{\mathrm{d}} \\
(18.510)\end{array}$ \\
\hline $\mathbf{A}_{7}$ & $\begin{array}{l}2.683^{\mathrm{b}} \\
(9.423)\end{array}$ & $\begin{array}{c}4.750^{\mathrm{d}} \\
(12.587)\end{array}$ & $\begin{array}{c}7.933^{\mathrm{d}} \\
(16.360)\end{array}$ & $\begin{array}{l}10.017^{\mathrm{d}} \\
(18.447)\end{array}$ \\
\hline A8 & No decay & $\begin{array}{l}2.773^{\mathrm{c}} \\
(9.583)\end{array}$ & $\begin{array}{c}5.763^{c} \\
(13.887)\end{array}$ & $\begin{array}{c}7.867^{\mathrm{c}} \\
(16.287)\end{array}$ \\
\hline A9 & No decay & $\begin{array}{l}1.593^{\mathrm{a}} \\
(7.247)\end{array}$ & $\begin{array}{c}3.590^{\mathrm{a}} \\
(10.923)\end{array}$ & $\begin{array}{c}6.357^{\mathrm{a}} \\
(14.600)\end{array}$ \\
\hline SE & 0.117 & 0.137 & 0.183 & 0.154 \\
\hline CD at $1 \%$ & 0.475 & 0.556 & 0.745 & 0.628 \\
\hline
\end{tabular}

-` indicates termination of treatments

Figures in parentheses indicates Arcsine value.

\section{Dipping treatments (Coatings):}

$\mathbf{A}_{1}=$ Control

$\mathbf{A}_{2}=10 \%$ Honey 
$\mathbf{A}_{3}=20 \%$ Honey

$\mathbf{A}_{5}=10 \%$ Whey protein concentrations (WPC)

$\mathbf{A}_{7}=$ Calcium chloride $\left(2.5 \%\right.$ at $\left.60{ }^{\circ} \mathrm{C}\right)$

$\mathbf{A} 9=0.1 \%$ Nano silver stipulated Food grade level $\mathrm{H}_{2} \mathrm{O}_{2}$
$\mathbf{A}_{4}=$ Aloe vera gel

$\mathbf{A}_{6}=$ Calcium chloride $\left(2.5 \%\right.$ at $\left.20{ }^{\circ} \mathrm{C}\right)$

$\mathbf{A} 8=$ Calcium lactate $(1 \%)$
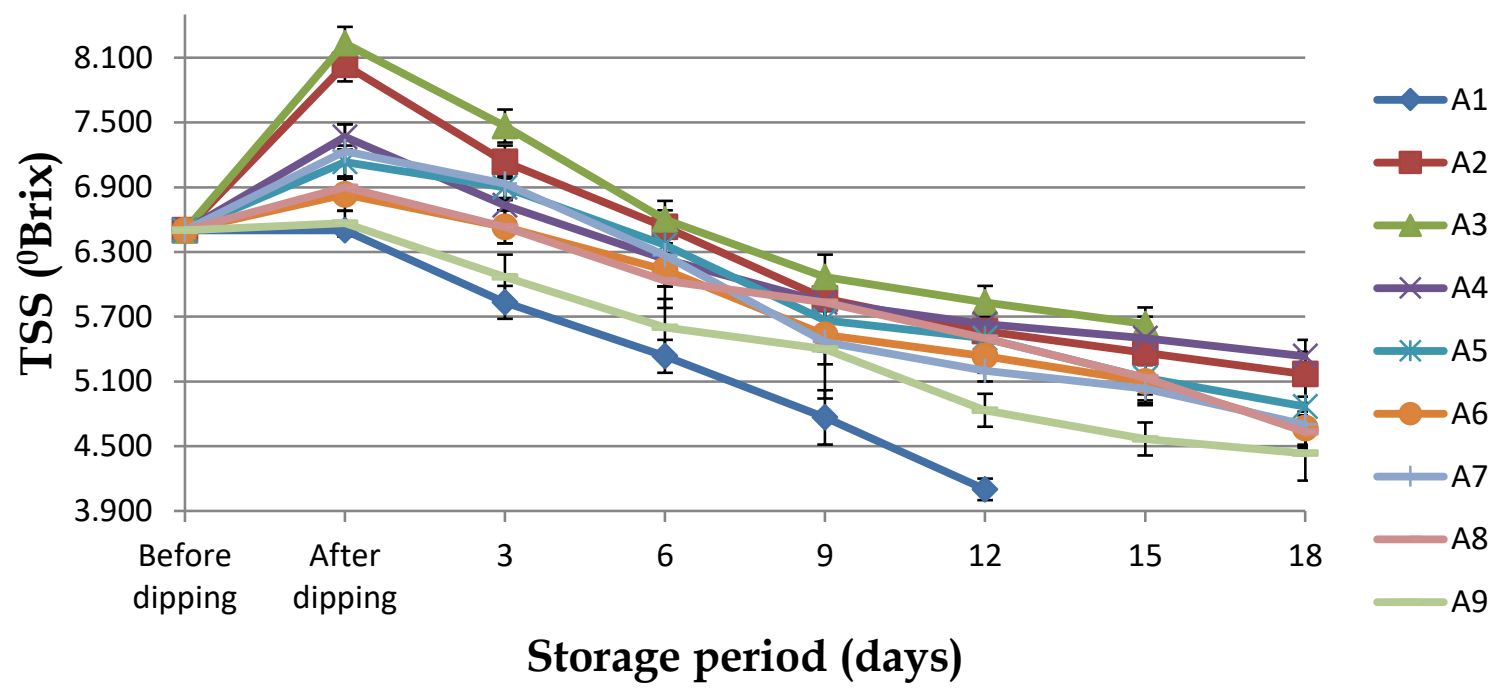

Storage period (days)

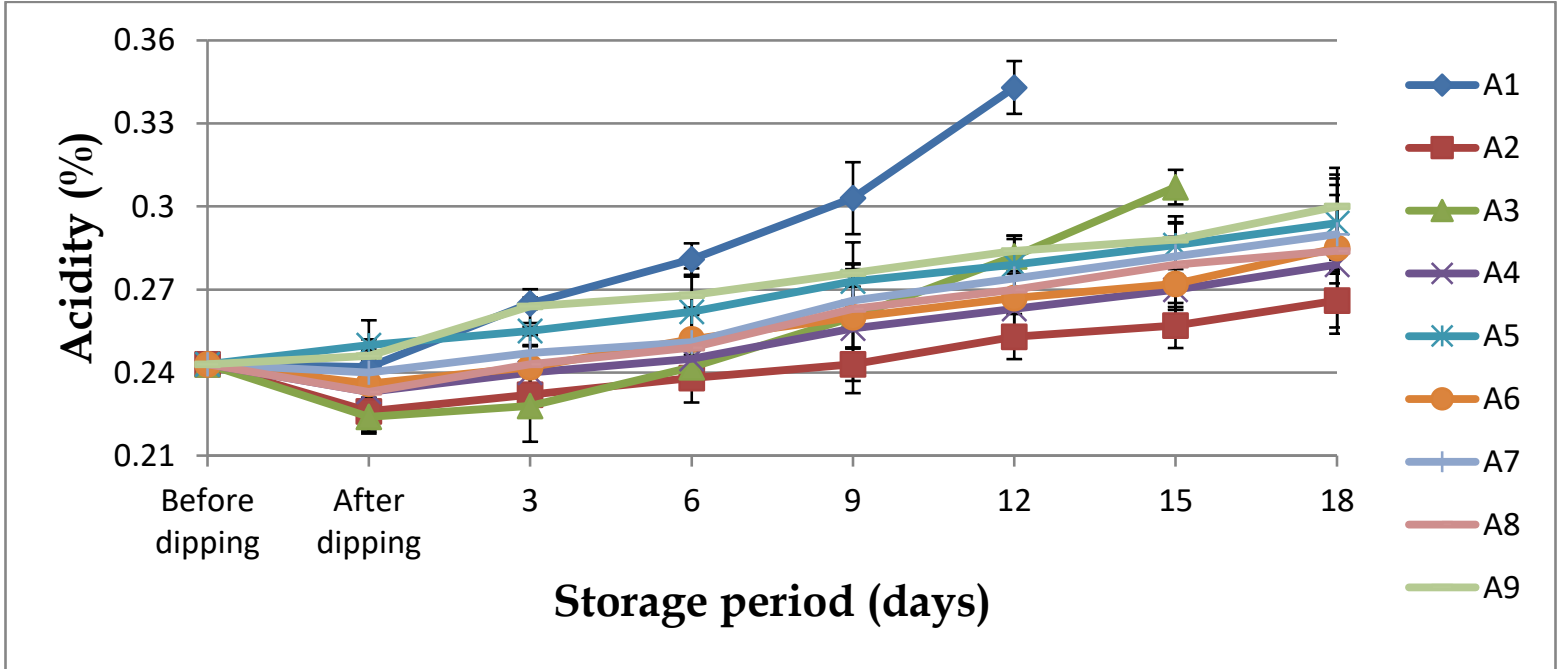

Dipping treatments (Coatings):

$\mathbf{A}_{1}=$ Control

$\mathbf{A}_{3}=20 \%$ Honey

$\mathbf{A}_{5}=10 \%$ Whey protein concentrations (WPC)

$\mathbf{A}_{7}=$ Calcium chloride $\left(2.5 \%\right.$ at $\left.60{ }^{\circ} \mathrm{C}\right)$

$\mathbf{A}_{9}=0.1 \%$ Nano silver stipulated Food grade level $\mathrm{H}_{2} \mathrm{O}_{2}$
$\mathbf{A}_{2}=10 \%$ Honey

$\mathbf{A}_{4}=$ Aloe vera gel

$\mathbf{A}_{6}=$ Calcium chloride $\left(2.5 \%\right.$ at $\left.20{ }^{\circ} \mathrm{C}\right)$

$\mathbf{A} 8=$ Calcium lactate (1\%)

Fig.2: Effect of dipping treatments (coatings) on the TSS and Acidity of the fresh-cut muskmelon stored at refrigerated storage $5 \pm 1^{0} C$. 


\section{Microbial Limits Test}

The high humidity within a package and the presence of large area of cut surfaces, which provide a rich source of nutrients, create an environment conducive to growth of microorganisms. During storage, the colony growth substantially depends on dippings treatment, experimental material, packaging method and storage time. Initial total aerobic count in fresh-cut muskmelon was 5.373 $\log \mathrm{cfu} \mathrm{g}^{-1}$ while it was reduced to $1.980 \log \mathrm{cfu} \mathrm{g}^{-1}$ and 3.980 $\log \mathrm{cfu}^{-1}$ at final day of storage i.e. 18 days after storage in the fresh-cut muskmelon pretreated with 0.1 per cent nanosilver stipulated food grade hydrogen peroxide $\left(\mathrm{A}_{9}\right)$ (Table 2). Significantly minimum total yeast and mold count was observed in 0.1 per cent nanosilver stipulated food grade hydrogen peroxide before dipping treatments, recorded was $4.273 \log \mathrm{cfu} \mathrm{g}^{-1}$. After dipping $1.875 \log \mathrm{cfu} \mathrm{g}^{-1}$ at day 0 . At the end of storage period, significantly minimum count (2.801 log cfu g-1). This might be due to sterilization effect of nanosilver and hydrogen peroxide sanitizer antibacterial biofilm coating on the fresh cut muskmelon which prevented enzymatic browning and discolouration of the fresh-cut muskmelon and had suppressing effect on microbes growth. The results of present study are in accordance with those of Mukundan (2007) in vegetables, Dhumal (2012) in pomegranate arils, Ayhan and Chism, (1998) in minimally processed fresh-cut cantaloupe and honeydew melons, Zhang et al. (2005) and Allende et al. (2009) in fresh-cut muskmelon.

\section{Sensorial analysis}

Evaluation of all dipping (coatings) treatments was carried out using 9 point hedonic scale (Portela and Cantwell, 1998). The pre-treatment of fresh-cut muskmelon with $10 \%$ whey protein concentrate for 1 minute and packaged in pint glass jar maintained or enhanced colour and appearance, taste, flavor, retained freshness and maintained fresh like quality up to 18 days at $5^{\circ} \mathrm{C}$ followed by in 0.1 per cent Nano silver stipulated food grade hydrogen peroxide (Table 3, 4, 5 and table 6). The control treatment showed loss of organoleptic quality throughout the storage period which might be due to increase in lightness, whiteness, discolouration, translucency and texture loss as reported by Haffez et al. (2016), Khuram et al. (2015), Silveira et al. (2011) in melons. Calcium chloride recorded low score (5.966) for flavor and taste (5.706) next to untreated control, which might be the consequences of auto-oxidation of fats, breakdown of proteins having sulphur containing amino acid, both of which give rise to rancid off-flavors and also due to bitterness or off-flavour associated with salt as reported by Luna-Guzman et al. (2000). This might be due to the active proteins present in WPC which possess oxygen barrier properties resulting reduced rate of respiration, reduced moisture loss and surface wounding holding the fresh-cut tissues firmly as reported by Ghavidel et al. (2013) in freshcut apples. Further, WPC coating has anti-browning and antimicrobial properties with antioxidant activity maintaining good colour, appearance and odour of fruit slices.

Table 2. Effect of dipping treatments (coatings) on the total aerobic count $\left(\log c f u g^{-1}\right)$ and yeast and mould count $\left(\log c f u g^{-1}\right)$ of the fresh-cut muskmelon stored at $5 \pm 1^{\circ} \mathrm{C}$.

\begin{tabular}{|c|c|c|c|c|c|c|}
\hline \multirow[t]{3}{*}{ Treatment } & \multirow{2}{*}{\multicolumn{3}{|c|}{$\begin{array}{c}\text { Total aerobic count }\left(\log \text { cfu g }^{-1}\right) \\
\text { Storage noriod in days }\end{array}$}} & \multirow{2}{*}{\multicolumn{3}{|c|}{$\begin{array}{l}\text { Yeast and mould count }\left(\log \mathrm{cfu} \mathrm{g}^{-1}\right) \\
\text { Storage period in }\end{array}$}} \\
\hline & & & & & & \\
\hline & $\begin{array}{l}\text { Initial before } \\
\text { dipping }\end{array}$ & $\begin{array}{l}\text { Initial after } \\
\text { dipping }\end{array}$ & $\begin{array}{l}\text { Final day of } \\
\text { storage }\end{array}$ & $\begin{array}{l}\text { Initial before } \\
\text { dipping }\end{array}$ & $\begin{array}{l}\text { Initial after } \\
\text { dipping }\end{array}$ & $\begin{array}{l}\text { Final day of } \\
\text { storage }\end{array}$ \\
\hline$A_{1}$ & & $5.423^{\mathrm{d}}$ & $\begin{array}{c}9.967^{\mathrm{e}} \\
\left(12^{\text {th }} \text { day }\right)\end{array}$ & & $4.754^{\mathrm{f}}$ & $9.056^{\mathrm{e}}$ \\
\hline$\overline{A_{2}}$ & & $4.713^{\mathrm{cd}}$ & $\begin{array}{c}7.077^{\text {bc }} \\
\left(18^{\text {th }} \text { day }\right)\end{array}$ & & $3.494^{\mathrm{cd}}$ & $5.901^{\mathrm{b}}$ \\
\hline $\mathbf{A}_{3}$ & & $4.330^{\mathrm{c}}$ & $\begin{array}{c}6.827^{\mathrm{b}} \\
\left(15^{\text {th }} \text { day }\right)\end{array}$ & & $3.252^{\mathrm{bc}}$ & $5.801^{\mathrm{b}}$ \\
\hline $\mathbf{A}_{4}$ & & $4.697^{c}$ & $\begin{array}{c}7.263^{\text {bc }} \\
\left(18^{\text {th }} \text { day }\right)\end{array}$ & & $3.717^{\mathrm{de}}$ & $5.869^{\mathrm{b}}$ \\
\hline
\end{tabular}




\begin{tabular}{|c|c|c|c|c|c|c|}
\hline $\mathbf{A}_{5}$ & 5.373 & $4.743^{c}$ & $\begin{array}{c}6.670^{\mathrm{b}} \\
\left(18^{\text {th }} \text { day }\right)\end{array}$ & 4.273 & $3.982^{\text {de }}$ & $5.701^{\mathrm{b}}$ \\
\hline $\mathbf{A}_{6}$ & & $5.207^{\mathrm{d}}$ & $\begin{array}{c}8.830^{\mathrm{de}} \\
\left(18^{\text {th }} \text { day }\right)\end{array}$ & & $4.187^{\mathrm{f}}$ & $7.936^{\mathrm{d}}$ \\
\hline $\mathbf{A}_{7}$ & & $3.903^{b}$ & $\begin{array}{c}8.030^{\text {cd }} \\
\left(18^{\text {th }} \text { day }\right)\end{array}$ & & $2.982^{\mathrm{b}}$ & $6.987^{c}$ \\
\hline $\mathbf{A s}_{8}$ & & $4.380^{c}$ & $\begin{array}{c}7.753^{\text {bc }} \\
\left(18^{\text {th }} \text { day }\right)\end{array}$ & & $3.867^{\mathrm{ef}}$ & $6.886^{\mathrm{bc}}$ \\
\hline A9 & & $1.980^{\mathrm{a}}$ & $\begin{array}{c}3.980^{\mathrm{a}} \\
\left(18^{\text {th }} \text { day }\right)\end{array}$ & & $1.875^{\mathrm{a}}$ & $2.801^{\mathrm{a}}$ \\
\hline $\mathbf{S E}$ & - & 0.198 & 0.374 & - & 0.163 & 0.308 \\
\hline CD at $1 \%$ & - & 0.760 & 1.440 & - & 0.627 & 1.185 \\
\hline
\end{tabular}

Dipping treatments (Coatings):

$\mathbf{A}_{1}=$ Control

$\mathbf{A}_{3}=20 \%$ Honey

$\mathbf{A} 5=10 \%$ Whey protein concentrations (WPC)

$\mathbf{A}_{7}=$ Calcium chloride $\left(2.5 \%\right.$ at $\left.60{ }^{\circ} \mathrm{C}\right)$
$\mathbf{A}_{2}=10 \%$ Honey

$\mathbf{A} 4=$ Aloe vera gel

$\mathbf{A}_{6}=$ Calcium chloride $\left(2.5 \%\right.$ at $\left.20{ }^{\circ} \mathrm{C}\right)$

$\mathbf{A} 8=$ Calcium lactate $(1 \%)$

$\mathbf{A}_{9}=0.1 \%$ Nano silver stipulated Food grade level $\mathrm{H}_{2} \mathrm{O}_{2}$

Table 3. Effect of dipping treatments (coatings) on the color and appearance (score) and taste (score) of the fresh-cut muskmelon stored at $5 \pm 1^{0} \mathrm{C}$.

\begin{tabular}{|c|c|c|c|c|c|c|c|c|}
\hline \multirow[t]{3}{*}{ Treatments } & \multicolumn{4}{|c|}{ Color and appearance (Score) } & \multicolumn{4}{|c|}{ Taste (Score) } \\
\hline & \multicolumn{4}{|c|}{ Storage period in days } & \multicolumn{4}{|c|}{ Storage period in days } \\
\hline & 3 & 6 & 12 & 18 & 3 & 6 & 12 & 18 \\
\hline Initial value & 8.00 & 8.00 & 8.00 & 8.00 & 9.00 & 9.00 & 9.00 & 9.00 \\
\hline $\mathbf{A}_{1}$ & $7.333^{\mathrm{c}}$ & $6.000^{\mathrm{e}}$ & $4.367^{\mathrm{e}}$ & - & $7.867^{\mathrm{c}}$ & $6.933^{\mathrm{e}}$ & $5.500^{\mathrm{f}}$ & - \\
\hline $\mathbf{A}_{2}$ & $7.433^{\mathrm{ab}}$ & $7.067^{\mathrm{d}}$ & $6.254^{\mathrm{c}}$ & $5.998^{\text {bcd }}$ & $8.400^{\mathrm{a}}$ & $7.967^{\mathrm{bc}}$ & $7.000^{\mathrm{abc}}$ & $6.107^{\mathrm{ab}}$ \\
\hline $\mathbf{A}_{3}$ & $7.800^{\mathrm{abc}}$ & $7.200^{\mathrm{bcd}}$ & $5.933^{\mathrm{d}}$ & - & $8.333^{\mathrm{ab}}$ & $7.833^{\mathrm{cd}}$ & $6.500^{\mathrm{e}}$ & - \\
\hline $\mathbf{A}_{4}$ & $7.400^{\mathrm{bc}}$ & $7.100^{\mathrm{cd}}$ & $6.225^{c}$ & $5.869^{d}$ & $8.467^{b}$ & $8.033^{\mathrm{ab}}$ & $7.067^{\mathrm{ab}}$ & $6.243^{\mathrm{ab}}$ \\
\hline $\mathbf{A}_{5}$ & $7.967^{\mathrm{a}}$ & $7.500^{\mathrm{a}}$ & $6.551^{\mathrm{a}}$ & $6.209^{\mathrm{a}}$ & $8.600^{\mathrm{a}}$ & $8.167 \mathrm{a}$ & $7.167^{\mathrm{a}}$ & $6.371^{\mathrm{a}}$ \\
\hline $\mathbf{A}_{6}$ & $7.500^{\mathrm{abc}}$ & $7.133^{\mathrm{cd}}$ & $6.240^{c}$ & $5.980^{\mathrm{cd}}$ & $8.233^{\mathrm{ab}}$ & $7.633^{d}$ & $6.667^{\mathrm{de}}$ & $5.706^{b}$ \\
\hline $\mathbf{A}_{7}$ & $7.333^{\mathrm{bc}}$ & $7.067^{\mathrm{d}}$ & $6.349^{\mathrm{bc}}$ & $6.004^{\text {bcd }}$ & $8.267^{\mathrm{b}}$ & $7.700^{\mathrm{d}}$ & $6.700^{\mathrm{de}}$ & $5.763^{b}$ \\
\hline A8 & $7.900^{\mathrm{abc}}$ & $7.367^{\mathrm{ab}}$ & $6.323^{b c}$ & $6.087^{\mathrm{abc}}$ & $8.300^{\mathrm{ab}}$ & $7.767^{\mathrm{cd}}$ & $6.733^{\mathrm{cde}}$ & $5.833^{\mathrm{ab}}$ \\
\hline A9 & $7.600^{\mathrm{abc}}$ & $7.300^{\mathrm{abc}}$ & $6.424^{\mathrm{ab}}$ & $6.153^{\mathrm{ab}}$ & $8.100^{\mathrm{ab}}$ & $7.767^{\mathrm{cd}}$ & $6.833^{\mathrm{bcd}}$ & $6.292^{\mathrm{ab}}$ \\
\hline SE & 0.187 & 0.068 & 0.053 & 0.050 & 0.060 & 0.063 & 0.092 & 0.058 \\
\hline CD at $1 \%$ & 0.761 & 0.275 & 0.214 & 0.205 & 0.244 & 0.256 & 0.373 & 0.237 \\
\hline
\end{tabular}


Table 4. Effect of dipping treatments (coatings) on the flavour (score) and overall acceptability (score) of the fresh-cut muskmelon stored at $5 \pm l^{0} \mathrm{C}$.

\begin{tabular}{|c|c|c|c|c|c|c|c|c|}
\hline \multirow[t]{3}{*}{ Treatments } & \multicolumn{4}{|c|}{ Flavour (Score) } & \multicolumn{4}{|c|}{ Overall acceptability (Score) } \\
\hline & \multicolumn{4}{|c|}{ Storage period in days } & \multicolumn{4}{|c|}{ Storage period in days } \\
\hline & 3 & 6 & 12 & 18 & 3 & 6 & 12 & 18 \\
\hline Initial value & 9.00 & 9.00 & 9.00 & 9.00 & 9.00 & 9.00 & 9.00 & 9.00 \\
\hline $\mathbf{A}_{1}$ & $7.900^{\mathrm{d}}$ & $7.333^{\mathrm{d}}$ & $5.767^{\mathrm{e}}$ & - & $7.700^{\mathrm{b}}$ & $6.755^{\mathrm{b}}$ & $5.211^{\mathrm{b}}$ & - \\
\hline $\mathbf{A}_{2}$ & $8.467^{\mathrm{b}}$ & $7.967^{\mathrm{b}}$ & $6.933^{\mathrm{b}}$ & $6.173^{\mathrm{b}}$ & $8.100^{\mathrm{ab}}$ & $7.734^{\mathrm{a}}$ & $6.785^{\mathrm{a}}$ & $6.093^{\text {bcd }}$ \\
\hline A3 & $8.233^{c}$ & $7.667^{\mathrm{c}}$ & $6.367^{\mathrm{d}}$ & - & $8.122^{\mathrm{ab}}$ & $7.567^{\mathrm{ab}}$ & $6.267^{\mathrm{a}}$ & - \\
\hline $\mathbf{A}_{4}$ & $8.600^{\mathrm{b}}$ & $8.167^{\mathrm{a}}$ & $7.167^{\mathrm{a}}$ & $6.302^{\mathrm{b}}$ & $8.156^{\mathrm{ab}}$ & $7.678^{\mathrm{a}}$ & $6.742^{\mathrm{a}}$ & $6.138^{\mathrm{abc}}$ \\
\hline A5 & $8.733^{\mathrm{a}}$ & $8.300^{\mathrm{a}}$ & $7.300^{\mathrm{a}}$ & $6.454^{\mathrm{a}}$ & $8.433^{\mathrm{a}}$ & $7.944^{\mathrm{a}}$ & $6.973^{\mathrm{a}}$ & $6.345^{\mathrm{a}}$ \\
\hline $\mathbf{A}_{6}$ & $8.267^{\mathrm{c}}$ & $7.800^{\mathrm{bc}}$ & $6.700^{\mathrm{bc}}$ & $5.966^{\mathrm{c}}$ & $8.000^{\mathrm{ab}}$ & $7.567^{\mathrm{ab}}$ & $6.558^{\mathrm{a}}$ & $5.884^{\mathrm{d}}$ \\
\hline $\mathbf{A}_{7}$ & $8.300^{c}$ & $7.833^{\mathrm{bc}}$ & $6.733^{\mathrm{bc}}$ & $5.943^{\mathrm{c}}$ & $7.989^{\mathrm{ab}}$ & $7.533^{\mathrm{ab}}$ & $6.594^{\mathrm{a}}$ & $5.903^{\mathrm{d}}$ \\
\hline A8 & $8.367^{\mathrm{bc}}$ & $7.900^{\mathrm{b}}$ & $6.833^{\mathrm{bc}}$ & $6.008^{c}$ & $8.033^{\mathrm{ab}}$ & $7.633^{\mathrm{a}}$ & $6.608^{\mathrm{a}}$ & $5.976^{\mathrm{cd}}$ \\
\hline A9 & $8.433^{\mathrm{b}}$ & $7.933^{\mathrm{b}}$ & $6.900^{\mathrm{bc}}$ & $6.257^{\mathrm{b}}$ & $8.044^{\mathrm{ab}}$ & $7.733^{\mathrm{a}}$ & $6.775^{\mathrm{a}}$ & $6.234^{\mathrm{ab}}$ \\
\hline SE & 0.043 & 0.061 & 0.069 & 0.045 & 0.261 & 0.265 & 0.238 & 0.072 \\
\hline CD at $1 \%$ & 0.175 & 0.248 & 0.283 & 0.183 & 1.064 & 1.079 & 0.967 & 0.293 \\
\hline
\end{tabular}

\section{Dipping treatments (Coatings):}

$\mathbf{A}_{1}=$ Control

$\mathbf{A}_{\mathbf{3}}=20 \%$ Honey

$\mathbf{A}_{5}=10 \%$ Whey protein concentrations (WPC)

$\mathbf{A}_{7}=$ Calcium chloride $\left(2.5 \%\right.$ at $\left.60{ }^{\circ} \mathrm{C}\right)$

$\mathbf{A}_{9}=0.1 \%$ Nano silver stipulated Food grade level $\mathrm{H}_{2} \mathrm{O}_{2}$
$\mathbf{A}_{2}=10 \%$ Honey

$\mathbf{A}_{4}=$ Aloe vera gel

$\mathbf{A}_{\mathbf{6}}=$ Calcium chloride $\left(2.5 \%\right.$ at $\left.20{ }^{\circ} \mathrm{C}\right)$

$\mathbf{A} 8=$ Calcium lactate $(1 \%)$

\section{CONCLUSION}

The pre-treatment of fresh-cut muskmelon with organic treatment $10 \%$ Whey protein concentrate (WPC) packaged in pint glass jar effectively controlled decay, restricted microbial growth with minimum changes in physicochemical attributes and maintained or enhanced colour, taste, flavor, retained freshness and maintained fresh like quality up to 18 days at $5 \pm 1^{\circ} \mathrm{C}$. As regards, the inorganic dipping treatments tried, the pretreatments with 0.1 per cent nanosilver stabilized food grade hydrogen peroxide were the recorded minimum decay as well as microbial population in the packaged samples throughout the storage period at $5 \pm 1^{0} \mathrm{C}$.

\section{REFERENCES}

[1] A.O.A.C., 2005. International Official Methods of Analysis. $18^{\text {th }}$ Edn., Association of Official Analytical Chemists, Washington, Dc., U.

[2] Allende, A., McEvoy, Tao, Y. and Luo, Y. 2009. Antimicrobial effect of acidified sodium chlorite, sodium chlorite, sodium hypochlorite and citric acid on Escherichia coli $\mathrm{O} 157: \mathrm{H} 7$ and natural microflora of fresh-cut cilantro. Food Control 20: 230-234.

[3] Amaro, A. L., Beaulieu, J. C., Grimm, C. C., Stein, R.E. and Almeida, D. P. F. 2012. Effect of oxygen on aroma atiles and quality of fresh-cut cantaloupe and honeydew melons. Food Chem. 130(1): 49-57.

[4] Anonymous, 2016. Indian Horticulture Database-2015. Pub. National Horticulture Board, Ministry of Agriculture, Govt. of India. 
[5] Ayhan, Z. and Chism, G. W. 1998. The shelf-life of minimally processed fresh-cut melons. J. Food Quality 21: 29-40.

[6] Baldwin, E. A., Nisperos-Carriedo, M. O., Baker, R. A. 1995. Use of edible coatings to preserve quality of lightly processed products. Critical Reviews in Food Sci. and Nutri. 35: 509-52.

[7] Beaulieu, J. C. and Gorny, J. R. 2002. Fresh cut fruits. http://www.ba.ars.usda.gov/hb66/146freshcutfruits.pdf (accessed 1. 12. 2007).

[8] Bernstein, Michael, 2005. Aloe vera coating for fruits and vegetables. Washington DC.

[9] Dhumal, S. S. 2012. Studies on processing of pomegranate (Punica granatum L.) into value added products. A Ph. D. thesis submitted to M. P. K. V., Rahuri.

[10] Dhumal, S. S., Karale, A. R., Jadhav, S. B. and Kad, V. P. 2014. Recent advances and the developments in the pomegranate processing and utilization: A Review J. Agric. and Crop Sci. 1: 01-17.

[11] Ergun, M. and Ergun, N. 2009. Maintaining quality of minimally processed pomegranate arils by honey treatments. British Food J. 111(4): 396-406.

[12] Ghavidel, R. A., Davoodi, M. G., Asl, A. F. A., Tanoori, T., Sheykholeslami, Z. 2013. Effect of selected edible coatings to extend shelf-life of fresh-cut apples. Int. J. Agric. Crop Sci. 616: 1171-1178.

[13] Gihan, G. A. 2010. Effect of gamma radiation on microbial load and chemical constituents of banana fruits stored under different temperatures. Res. J. Agril. Biol. Sci. 6(4): 431-442.

[14] Gil, M. I., Artes, F. and Tomas-Barberan, F. A. 1996. Minimal processing and modified atmosphere packaging effects on pigmentation of pomegranate seeds. J. Food Sci. 61: 161-164.

[15] Haffez, M. M., Ragab, M. E., El-Yazied, A. A. and Emam, M. S. 2016. Effect of chitosan, carboxy methyl cellulose and calcium chloride treatments on quality and storability of freshcut cantaloupe. Middle East J. Applied Sci. 06: 249-268.

[16] Kester, J. J. and Fennema, O. R. (1988). Edible films and coatings. A review. Food Technol. 42: 47-59. CRC Press, Boca Raton, FL.

[17] Khuram, H., Aslam,W., Sakandar, H. A., Asim, M., and Shakeel, A. 2015. Impact of Various biodegradable coatings on shelf life of minimally Processed melon. J. Glob. Innov. Agric. Soc. Sci. 3(1):19-24.

[18] Koh, P. C., Noranizan, M. A., Hanani, Z. A. N., Karim, R. and Rosli, S. Z. 2017. Application of edible coatings and repetitive pulsed light for shelf life extension of fresh-cut cantaloupe (Cucumis melo L. reticulatus cv. Glamour). Postharvest Biol. Technol. 129: 64-78.

[19] Lamikanra, O. and Watson, M. A. 2007. Mild heat and calcium treatment effects on fresh-cut cantaloupe melon during storage. Food Chem. 102: 1383-1388.

[20] *Lamikanra, O., Chen, J. C., Banks, D. and Hunter, P. A. 2000. Biochemical and microbial changes during the storage of minimally processed cantaloupe. J. Agric. Food Chem. 48(12): 5955-5961. DOI: 10.1021/jf0000732.

[21] Luna-Guzman, I., and Barrett, D. M. 2000. Comparison of Calcium chloride and Calcium lactate effectiveness in maintaining shelf stability and quality of fresh-cut cantaloupes. Postharvest Biol. Technol. 19: 61-72.

[22] Machado, F. L. C., Alves, R. E., and Figueiredo, R. W. 2008. Application of 1- methylcyclopropene, calcium chloride and calcium amino acid Chelate on fresh-cut cantaloupe muskmelon. Pesq. agropec. bras., Brasilia. 43(5): 569-574.

[23] Mukundan, M. K. 2007. A certificate given to Veg. Protect, $\mathrm{M} / \mathrm{s}$. Advanced Agro-Tech, Thane by Central Institute of Fisheries Technology, Cochin vide. Certificate No. F.32/2007-QAM dated 06.12.2007.

[24] Park, H. J. 1999. Development of advanced edible coatings for fruits. Trends in Food Sci. Technol. 10: 254-260.

[25] Perez-Gago, M. B., Serra, M., del Rio, M. A. 2006. Color change of fresh-cut apples coated with whey protein concentrate- based edible coatigs. Postharvest Biol. Technol. 39: 84-92.

[26] Portela, S. I. and Cantwell, M. I. 1998. Quality changes of minimally processed honeydew melons stored in air or controlled atmosphere. Postharvest Biol. Technol. 14: 351357.

[27] Reyes, L. F., Villarreal, J. E. and Zevallos, L. C. 2007. The increase in antioxidant capacity after wounding depends on the type of fruit or vegetable tissue. Food Chem. 101: 12541262. DOI: 10.1016/j.foodchem.2006.03.032.

[28] Rolle, R. S. and Chism, G. W. 1987. Physiological consequences minimally processed fruits and vegetables. J. of Food Quality. 10(3): 157-177. DOI: 10.1111/j.17454557.1987.tb00856.x

[29] Shellhammer, T. H. and Krochta, J. M. 1997. Whey protein emulsion film performance: effect of lipid type and amount. $J$. Food Sci. 62: 390-394.

[30] Silveira, A. C., Aguayo, E., Chisari, M., Artes, F. 2011. Calcium salts and heat treatment for quality retention of freshcut 'Galia' melon. Postharvest Biol. Technol. 62: 77-84.

[31] Song, H. Y., Jo, W. S., Song, N. B., Min, S. C. and Song, K. B. 2013. Quality change of apple slices coated with Aloe vera gel during storage. J. Food Sci. 78 (6): C817-C822.

[32] Syahidah, K., Rosnah, S., Noranizan, M. A., Zaulia, O. and Anvarjon, A. 2015. Quality changes of fresh-cut cantaloupe (Cucumis melo L. var. reticulatus cv. Glamour) in different types of polypropylene packaging. Int. Food Res. J. 22: 753760.

[33] Viianueva, M. J., Tenorio, M. D., Esteban, M. A. and Mendoza, M. C. 2004. Composition changes during ripening of 2 cultivars of muskmelon fruits. Food Chem. 87: 179-185.

[34] Watada, A. E., Ko, N. P. and Minott, D. A. 1996. Factors affecting quality of fresh-cut horticultural products. Postharvest Biol. Technol. 9: 115-125. 
[35] Watada, A. E. and Qi, L. 1999. Quality of fresh-cut produce. Postharvest Biol. Technol. 15: 201-205.

[36] Yulianingsih, R., Maharani, D. M., Hawa, L. C., and Sholikhah, L. 2013. Physical quality observation of edible coating made from Aloe vera on cantaloupe ( $\underline{\text { Cucumis }} \underline{\text { melo }}$ L.) minimally processed. Pakistan J. nutri. 12(9): 800-805.

[37] Zhang, M., Xiao, G., Peng, J. and Salokhe, V. M. 2005. Effects of single and combined atmosphere packages on preservation of strawberries. Int. J. of Food Engg. 1(4).

[38] Zsivanovits, G., Zhelyazkov, S., Brashlyanova, B., Iserliyska, D., Yovkova, D. 2012. Effect of chitosan coating on quality of fresh-cut melon during the shelf-life. Advanced Res. in Scientific Areas, 3: 7. 